
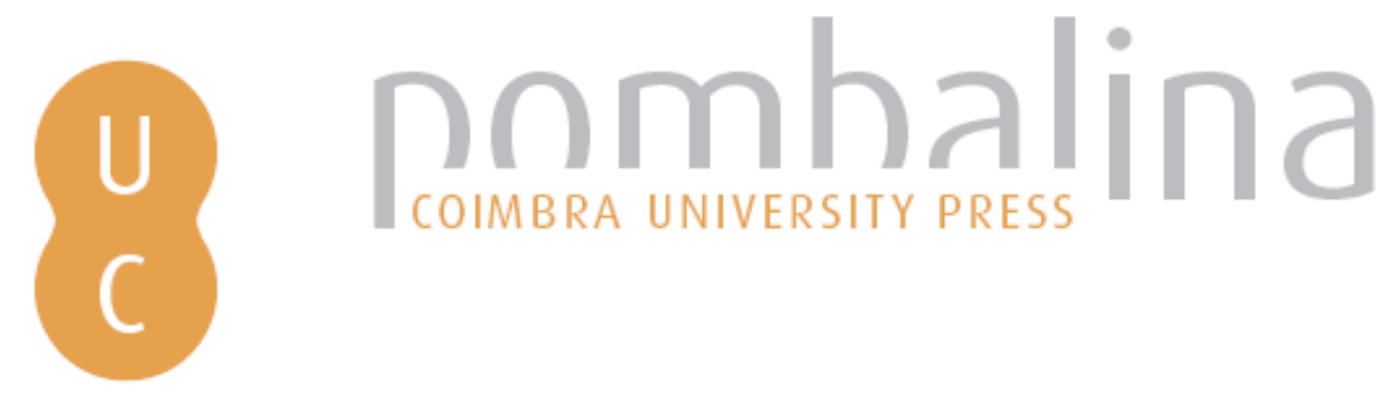

\title{
Escritores e jornalistas: um estudo de caso
}

\author{
Autor(es): $\quad$ Peixinho, Ana Teresa
}

Publicado por: Imprensa da Universidade de Coimbra

URL

persistente: $\quad$ URI:http://hdl.handle.net/10316.2/31638

DOI: $\quad$ DOI:http://dx.doi.org/10.14195/978-989-26-0199-1_29

Accessed : $\quad$ 26-Apr-2023 04:06:55

A navegação consulta e descarregamento dos títulos inseridos nas Bibliotecas Digitais UC Digitalis, UC Pombalina e UC Impactum, pressupõem a aceitação plena e sem reservas dos Termos e Condições de Uso destas Bibliotecas Digitais, disponíveis em https://digitalis.uc.pt/pt-pt/termos.

Conforme exposto nos referidos Termos e Condições de Uso, o descarregamento de títulos de acesso restrito requer uma licença válida de autorização devendo o utilizador aceder ao(s) documento(s) a partir de um endereço de IP da instituição detentora da supramencionada licença.

Ao utilizador é apenas permitido o descarregamento para uso pessoal, pelo que o emprego do(s) título(s) descarregado(s) para outro fim, designadamente comercial, carece de autorização do respetivo autor ou editor da obra.

Na medida em que todas as obras da UC Digitalis se encontram protegidas pelo Código do Direito de Autor e Direitos Conexos e demais legislação aplicável, toda a cópia, parcial ou total, deste documento, nos casos em que é legalmente admitida, deverá conter ou fazer-se acompanhar por este aviso.

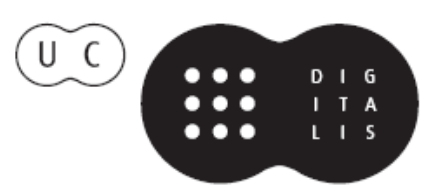


Maria Manuela Tavares Ribeiro

Coordenação

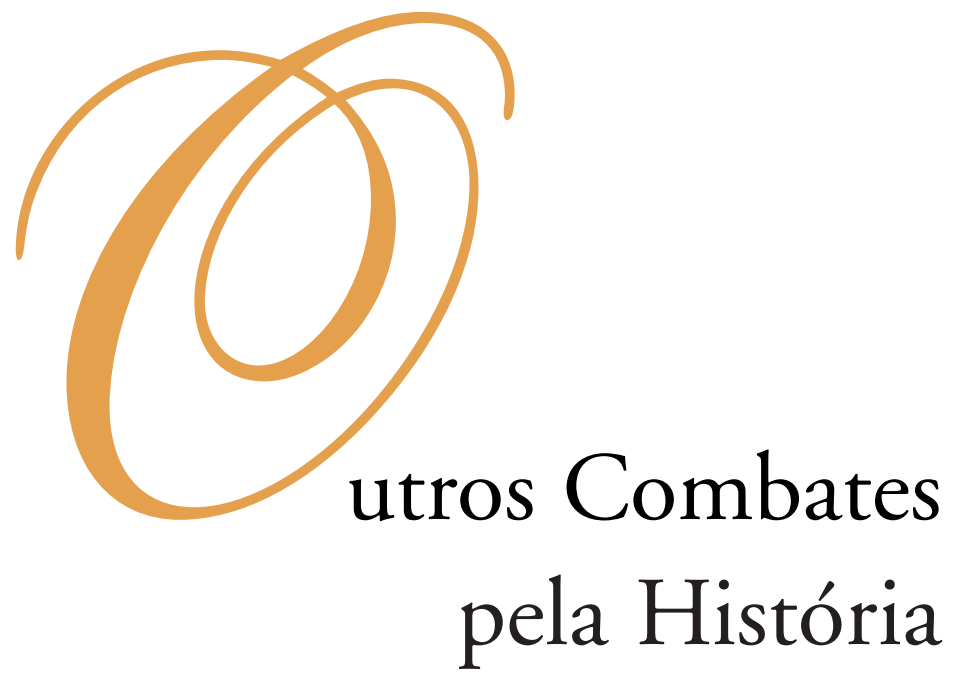




\section{COORDENAÇĀO EDITORIAL}

Imprensa da Universidade de Coimbra

Email: imprensauc@ci.uc.pt

URL: http://www.uc.pt/imprensa_uc

Vendas online: http://livrariadaimprensa.com

\section{CONCEPÇÃO GRÁFICA}

António Barros

\section{ORgANIZAÇĀO DOS TEXTOS}

Isabel Maria Luciano

Marlene Taveira

PRÉ-IMPRESSÃO

António Resende

Imprensa da Universidade de Coimbra

EXECUÇÃO GRÁFICA

SerSilito • Maia

ISBN

978-989-26-0041-3

DEPósito LEGAL

OBRA PUBLICADA COM O APOIO DE:

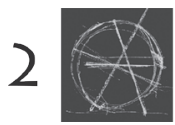

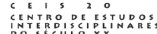

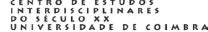

FCT Fundação para a Ciência e a Tecnologia

MINISTÉRIO DA CIÊNCIA, TECNOLOGIA E ENSINO SUPERIOR Portugal

Programa Operacional Ciência, Tecnologia, INOVAÇĀo DO QUADRo COMUNITÁRIO DE APOIO III

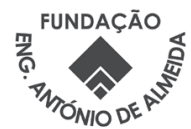

C JULHO 2010, IMPRENSA DA UNIVERSIDADE DE COIMBRA 
Maria Manuela Tavares Ribeiro

Coordenação

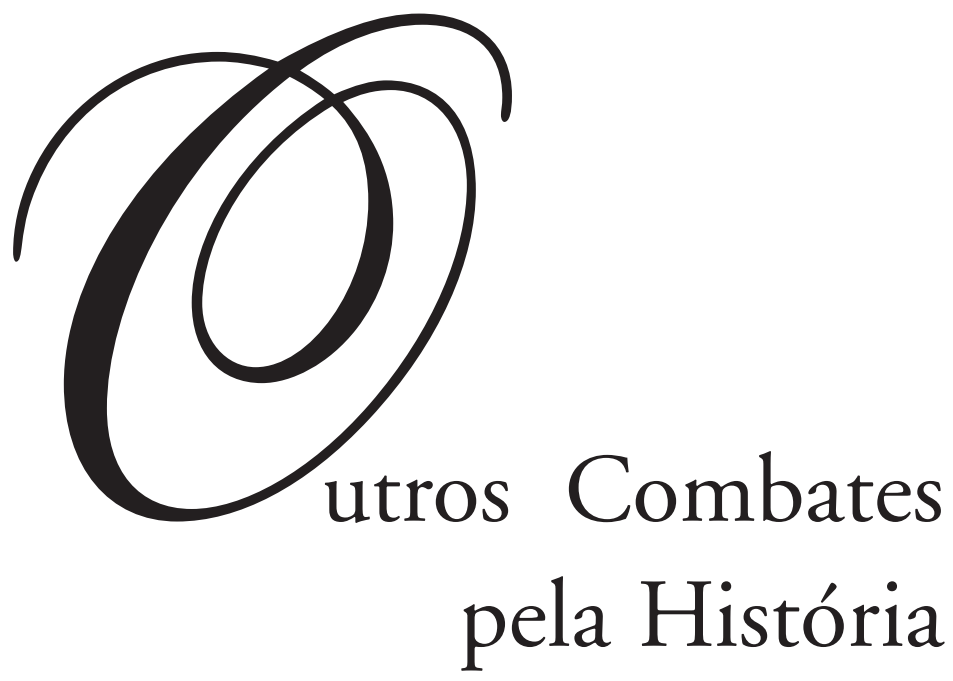

- colmbra 2010 
história, EducaÇÃo e ComunicaÇão 


\section{Ana Teresa Peixinho}

\section{ESCRITORES E JORNALISTAS: UM ESTUDO DE CASO}

1. O próprio preâmbulo deste evento afirma que se pretende debater, neste espaço, o sentido da História, numa lógica pluridisciplinar, entendendo-a como Ciência Social e Humana. Assim, dada a riqueza, a complexidade e a heterogeneidade da vida e da Obra do vulto que escolhemos, parece-nos adequado propor uma abordagem à faceta jornalística de Eça e, através dela, explorar algumas directrizes fundamentais da História da Imprensa Oitocentista.

Como é sabido, o século XIX, época áurea da imprensa, assistiu a um conjunto de mutações políticas, sociais e culturais, quase sempre lideradas por uma elite intelectual, nascida das Lutas Liberais e do Romantismo, extremamente interventiva em diversas áreas da sociedade.

De facto, se Eça de Queirós foi e é um escritor de renome, autor de várias obras de indiscutível mérito estético-artístico, que integram, enquanto tal, o cânone literário oitocentista, também não é menos verdade que a maleabilidade e a versatilidade da sua produção escrita abraçou outros géneros paraliterários que decorrem incontestavelmente do seu empenhamento nas questôes políticas e históricas do seu tempo.

Por outro lado, se a História pode ser entendida como a narrativa do que aconteceu e a Literatura a textualização do que poderia ter acontecido, no fundo, ambas fazem parte de uma macro-narrativa — também construída pelo discurso jornalístico - que nos permite ler, questionar, problematizar e decifrar o Homem e o seu Tempo.

2. À semelhança de muitos escritores portugueses do século XIX, Eça de Queirós manteve durante toda a sua vida activa uma relação de grande proximidade com o mundo da imprensa, em pleno florescimento durante todo o século. Desde a década de sessenta, quando redige e edita o jornal Distrito de Évora, até ao final dos anos noventa, no momento em que encerra a sua colaboração com o importante jornal brasileiro Gazeta de Notícias, Eça nunca se afasta dos jornais, quer como colaborador e correspondente, quer através de participações públicas pontuais, quer ainda pela publicação de alguma da sua ficção.

A ligação de Eça de Queirós ao jornalismo do seu tempo é, de facto, uma das marcas incontornáveis da sua vida e da sua obra, já que, desde os longínquos tempos 
dos folhetins dominicais de Prosas Bárbaras ${ }^{1}$, publicados na Gazeta de Portugal entre 1866 e 1867, até aos últimos anos da sua vida, o escritor manteve uma relação de grande proximidade com diversos jornais e revistas.

Essa relação adquiriu, ao longo dos anos, perfis de diferente natureza: nuns casos, o jornal cedeu a Eça, como aliás era comum no jornalismo da época, espaço de publicação e divulgação de algumas das suas obras; noutros, serviu de suporte e de medium à afirmação pública de determinados posicionamentos políticos, ideológicos ou estéticos, como o prova o elenco de suas cartas públicas ${ }^{2}$; finalmente, o jornalismo oitocentista enriqueceu-se com uma vastíssima colaboração cronística de Eça como correspondente exterior, como o demonstram as Cartas de Londres, publicadas no final da década de setenta no jornal $A$ Actualidade do Porto e o grande conjunto de textos com que o autor abrilhantou as páginas da Gazeta de Notícias do Rio de Janeiro, entre 1880 e 1897.

Para além destes três tipos de experiência que atestam a incontestável proximidade entre Eça e a imprensa do século XIX, não podemos de modo nenhum obliterar o importante papel do autor na feitura e direcção de outras publicaçôes: como director e redactor único do jornal regional Distrito de Évora, experiência da juventude que, como se sabe, foi fundamental na formação do escritor/jornalista; como colaborador empenhado d'As Farpas, projecto serial de índole reformista, partilhado com Ramalho Ortigão; como mentor e director da célebre Revista de Portugal, projecto editorial de altíssima qualidade, com fins pedagógicos e patrióticos indiscutíveis; como colaborador da Revista Moderna, periódico publicado em Paris, entre Maio de 1897 e Abril de 1899, da responsabilidade do brasileiro Martinho Carlos de Arruda Botelho e em que Eça publicou A Ilustre Casa de Ramires, três dos seus contos ("A Perfeição", "José Matias» e «Suave Milagre»), bem como algumas crónicas ${ }^{3}$. Além destes projectos de maior envergadura, há que ter também em consideração as colaborações pontuais com diversos jornais da época, tais como $O$ Atlântico, a Ilustração e $O$ Tempo, em que o escritor publica alguma da sua mais importante epistolografia pública, nomeadamente a célebre carta a Pinheiro Chagas «Brasil e Portugal», a carta-obituária em homenagem a Victor Hugo e a carta "Tomás de Alencar, uma explicação», respectivamente.

Aquilo que este elenco vem confirmar é a forte ligação de Eça de Queirós ao jornalismo oitocentista, uma ligação persistente, heterogénea e multifacetada. De facto, para além de grande romancista, Eça soube também, com muita mestria, cultivar outros tipos de escrita não ficcional, podendo afirmar-se, com verdade, que foi também um eminente jornalista do seu tempo. Esta é a opinião de muitos estudiosos da sua obra que reservam sempre um olhar atento à faceta jornalística da sua personalidade.

\footnotetext{
${ }^{1}$ A edição crítica destes textos redistribuiu-os e reeditou-os de outra forma, nomeadamente sob o título de Textos de Imprensa I (edição de Carlos Reis e Ana Teresa Peixinho). Apesar de tudo, utilizamos por comodidade o título escolhido por Luís de Magalhães, aquando da primeira edição em livro, em 1903, até porque, segundo os critérios da Edição Crítica, estes folhetins da Gazeta de Portugal foram redistribuídos entre Textos de Imprensa I, Contos e Epistolografia.

${ }^{2}$ Queirós, Eça de - Cartas Públicas, edição crítica de Ana Teresa Peixinho. Lisboa, INCM, 2009.

${ }^{3}$ Cf. Matos, A. Campos - Dicionário de Eça de Queiroz. Lisboa, Caminho, 1993. 2a ed., pp. 847-848.
} 
Jaime Brasil, num artigo já antigo intitulado «Eça de Queiroz, jornalista», considera Eça de Queirós um «jornalista de raça, isto é: de temperamento, de vocação, de amor apaixonado pelo ofício; jornalista profissional, pois durante certo período da sua vida só teve como únicos proventos os auferidos na imprensa; jornalista, visto ter exercido o mais nobre magistério possível de exercer em jornais: o de crítico; jornalista até ao escrever os seus romances, os quais, sob a capa romanesca, são ora panfletos de socio-crítica, ora doutrinação e norma de conduta.» ${ }^{4}$. Também Jacinto Baptista afirma que «se o jornalismo foi privilegiado meio de expressão e de comunicação de Eça com os leitores, nem por isso o episódico redactor do Distrito de Évora perdeu nunca, em relação aos jornais e à actividade dos jornalistas, o distanciamento crítico e a abordagem percuciente, irónico quando caso disso, que foi a sua constante atitude perante outras manifestações humanas.» 5

Bastará, para o constatarmos, que olhemos transversalmente para a sua obra, onde encontramos uma frequente e assídua colaboração em diversos periódicos do seu tempo; e tal colaboração não se restringe à publicação, em folhetim, de romances ou contos, como era habitual na época, uma vez que são bastantes as páginas de índole jornalística, através das quais o autor traça o panorama crítico da sociedade portuguesa, analisa friamente a situação política do país e do Mundo, descreve personalidades contemporâneas, acompanha a evolução de cenários internacionais, trava polémicas com outros indivíduos, analisa a imprensa internacional, etc. Claro que, em muitos destes casos, a colaboração de Eça com a imprensa permitia-lhe retirar dividendos extras que o ajudavam a suportar o estilo de vida para o qual o salário de diplomata era insuficiente. No entanto, apesar de o factor financeiro ter tido um peso bastante considerável na carreira jornalística de Eça de Queirós, acreditamos com Jacinto Baptista que «seria, porém, grave injustiça e erro notório limitar à preocupação lucrativa, de complemento à fonte de subsistência regular, a actividade periodística de Eça $(. ..){ }^{6}$.

3. Tendo em consideração o contexto histórico-cultural em que se move Eça de Queirós, convém referir que a acumulação das funções de escritor e jornalista era um facto muito comum. Como explica Isabel Vargues, a profissão de homem de letras era à época, cumulativa com outras, nomeadamente com a de jornalista: «Tal como em França, Inglaterra e Espanha também em Portugal os profissionais do jornalismo mantinham laços com a política e com a literatura, exercendo já então uma influência considerável na sociedade através de uma imprensa de opinião, que só mais tarde se tornaria noticiosa e informativa.» ${ }^{7}$. Num artigo sobre o homem de letras oitocentista, Fátima Outeirinho, recuperando o exemplo de Eça, afirma: «Eça de Queirós funciona como ilustração clara de uma experiência partilhada com tantos outros homens de

\footnotetext{
${ }^{4}$ Brasil, Jaime - «Eça de Queiroz, jornalista». In: Pereira, Lúcia Miguel e Reis, Câmara (orgs.) - Livro do Centenário de Eça de Queiroz. Lisboa, Livros do Brasil, 1945. pp. 509-520.

${ }^{5}$ Baptista, Jacinto - «Eça jornalista». In: Matos, A. Campos (org.) - Dicionário de Eça de Queiroz. Lisboa, Caminho, 1993. 2.a ed., p. 326.

${ }^{6}$ Idem, Ibidem. p. 326.

${ }^{7}$ Vargues, Isabel Nobre - «A Afirmação da Profissão de Jornalista em Portugal: um poder entre poderes?» In: Separata da Revista de História das Ideias. Coimbra, Faculdade de Letras, 2003. Vol. 24, pp. 158-159.
} 
letras do seu século, conjunto de experiências essas que nos conduz a equacionar o campo literário oitocentista como estando fortemente estribado numa relação íntima entre periodismo e literatura.» ${ }^{8}$

Este é, em nossa opinião, um aspecto incontornável da História do Jornalismo português que nos exige uma reflexão mais demorada. Na verdade, à semelhança do que sucede em França9, o nosso jornalismo vive, durante todo o século XIX intimamente dependente das esferas literária e política, sendo que muitos dos «jornalistas» eram simultaneamente políticos, deputados ou escritores: «todos os grandes nomes das nossas letras e do nosso pensamento colaboravam assiduamente na imprensa periódica, ao contrário do que acontecera, como vimos, nos séculos XVII e XVIII» ${ }^{10}$; e, segundo um testemunho de época, da autoria de Teixeira de Vasconcelos, director da Gazeta de Portugal, periódico em que Eça se estreou como folhetinista, "os escritores que são hoje o ornamento das letras nacionais, todos receberam o baptismo na pia jornalística e foram os gloriosos ascendentes da novíssima geração dos redactores portugueses.» ${ }^{11}$. Alguns estudiosos da História do jornalismo francês defendem mesmo que a sua especificidade, mais resistente à entrada da influência anglo-americana, se ficou a dever à dupla origem do seu jornalismo, simultaneamente político e literário, origem essa nunca renegada. Não nos cabe aqui desenvolver esta particularidade da história do jornalismo francês, mas basta observarmos os debates que ocorreram no fim do século XIX sobre a forma de fazer jornalismo em França, para percebermos as grandes fricções provocadas pela entrada dos modelos americanos no universo francês. Esta ligação dos homens de letras ao jornalismo processa-se, ao longo do século XIX, de diversas formas e é um fenómeno tipicamente europeu que trouxe consequências para a evolução das formas de fazer jornalismo. Note-se que o jornalismo inglês já no século XVIII vive esta aliança entre homens de letras e jornais: Daniel

\footnotetext{
${ }^{8}$ Outeirinho, Fátima - "A imprensa periódica e o folhetim na vida do homem de letras oitocentista». In: Queirosiana. Estudos sobre Eça de Queirós e sua Geração. Tormes, Fundação Eça de Queiroz, no 11/12, p. 82 .

${ }^{9}$ Para Thomas Ferenczi, esta dupla origem do jornalismo francês é uma das características identitárias da sua história, responsável inclusive pela forma híbrida e matizada com que o jornalismo absorveu, no final do século XIX, a vaga anglo-americana: «L'histoire du journalisme français montre en effet que celui-ci présente deux traits récurrents. Le premier est son lien avec la politique, le second sa relation avec la littérature." (Ferenczi, Thomas - L'invention du journalisme en France. Naissance de la presse moderne à la fin du XIXe siècle. Paris, Plon, 1993, p. 12.) Também Jean Chalaby, num estudo comparativo entre o jornalismo francês e o anglo-americano, defende que um dos motivos para o atraso na modernização do jornalismo em França se ficou a dever ao forte envolvimento entre imprensa, política e literatura: «Em França, nesse período, o jornalismo permaneceu sob a influência das suas esferas tradicionais de origem, a política e a literatura. A importância conferida à forma literária afastou dos jornais franceses o estilo telegráfico das notícias anglo-americanas. Além disso, um número significativo de jornalistas franceses continuava a escrever na tradição dos publicistas, numa escrita de propaganda de doutrinas políticas e de defesa dos interesses de um grupo político particular.» (Chalaby, Jean - "O Jornalismo como invenção anglo-americana. Comparação entre o desenvolvimento do jornalismo francês e anglo-americano (1830-1920)». In: Media \& Jornalismo, Nov. 2003, Vol. 1, n.o 3, p. 6. (http://revcom.portcom.intercom.org.br).

${ }^{10}$ Tengarrinha, José - História da Imprensa Periódica Portuguesa. Lisboa, Caminho, 1989. 2.a ed., p. 191.

${ }^{11}$ Vasconcelos, Teixeira, apud Venâncio, Fernando - «A Linguagem da Imprensa Portuguesa (1840-1870). Os testemunhos contemporâneos». In: Arquivos do Centro Cultural Calouste Gulbenkian. Lisboa-Paris, Centro Cultural Calouste Gulbenkian, 1996. Vol. XXXV, p. 385.
} 
Defoe, autor do célebre Robinson Crusoé, publicado em folhetins em 1719 no Daily Post, possuía um jornal - The Review; Joseph Addison, Dean Swift e Richard Steele foram os principais ensaístas ingleses da centúria de setecentos. J. Addison, escritor e político, escreve para The Tatler e também funda a revista The Spectator em 1711, com Richard Steele, também político e escritor. Dean Swift, famoso pelas suas Gulliver Travells, era irlandês, ensaísta, político e panfletário, tendo participado no The Tatler, The Examiner e The Spectator.

Antes da autonomização da profissão de jornalista, processo lento e apenas concluído no final do século, através da organização de Congressos Internacionais e da criação de Associações profissionais e de sindicatos, os jornais eram dirigidos e escritos em parte por escritores e intelectuais que viam o jornal como um modo de angariar público leitor e como forma de compensar o parco sustento conseguido com a venda dos livros. Esta realidade verifica-se também em França, onde, como explica Marie-Ève Thérenty, as difíceis condiçôes económicas dos homens de letras, devido à abolição das pensões e do mecenato, levam os escritores a procurar escritas mais lucrativas $^{12}$.

$\mathrm{Na}$ verdade, antes de se atingir a autonomia profissional, na viragem do século XIX para o século XX, ser jornalista era já uma profissão mas era também uma ocupação reservada quer a literatos, quer a políticos, que entendiam os jornais e as revistas como espaços públicos de opiniāo. Escrever nos jornais era uma forma de afirmação de uma autoridade, um modo de publicitar ideias, de divulgar obras, de defender ideologias, de travar polémicas diversas, enfim, de participar activamente na construção da esfera pública. Desde o nosso primeiro Romantismo, ideologicamente iluminado pelo Liberalismo, os nossos escritores movimentam-se simultaneamente no mundo da Literatura e no dos jornais: a título de exemplo, lembremos que em 1846 surge a Associação Promotora dos Melhoramentos da Imprensa, liderada por Almeida Garrett e José Estêvão, que agrupou um conjunto de escritores e jornalistas, a fim de reflectirem sobre o desenvolvimento da imprensa nacional ${ }^{13}$.

$\mathrm{Na}$ verdade, foi este período da História Portuguesa que, pela sua especificidade, melhor projectou a importância do jornal como veículo ideológico e como meio de combate. O período que José Tengarrinha apelida de imprensa romântica ou de opiniāo foi construído pelo empenhamento das grandes penas da nação, que depressa entenderam o importante potencial revolucionário dos jornais. Não é coincidência que seja precisamente neste período que começam a surgir certas vozes críticas contra os jornais e os jornalistas, como o já conhecido libelo de José Agostinho de Macedo, com o sintomático título Exorcismos contra Periódicos e outros malefícios, publicado em $1821^{14}$. José Agostinho de Macedo ${ }^{15}$ foi uma figura polémica do início do século XIX:

\footnotetext{
12 Thérenty, Marie-Ève - Mosäques. Être écrivain entre presse et roman (1829-1836). Paris, Honoré Champion, 2003, p. 21.

${ }^{13}$ A este respeito, veja-se: Tengarrinha, José - Ibidem, pp. 191-192.

${ }^{14}$ Este libelo foi publicado na Oficina da Viúva de Lino da Silva Godinho, com licença da Comissão de Censura.

${ }^{15}$ Veja-se: Coelho, Jacinto do Prado - Dicionário de Literatura. Porto, Figueirinhas, 1994. Vol. II, pp. 588-589.
} 
franciscano expulso da Ordem, satirista, polemista, crítico acérrimo dos ideais iluministas franceses, sobretudo após as Invasões Napoleónicas, este homem foi um defensor da causa miguelista, tendo atingido, através dos seus escritos violentos e pessoais, muitos dos nossos liberais, nomeadamente Garrett ${ }^{16}$. É uma figura incontornável do movimento panfletário português, tendo sempre como alvo os partidários do regime constitucional, como o ilustra o célebre panfleto A Besta Esfolada de 1828-29. O texto Exorcismos contra Periódicos e outros malefícios é um dos muitos textos escritos sobre jornalismo, já que este autor é o primeiro a encabeçar a lista dos mais produtivos estudiosos do Jornalismo ${ }^{17}$. No entanto, este texto não possui uma dimensão académica ou teorética, sendo antes um ataque verrinoso à proliferação de periódicos liberais e aos seus agentes, viperinamente chamados de "periodiqueiros». De qualquer forma, podemos entendê-lo como um sintoma do importante e crescente peso da imprensa na constituição da opinião pública, neste conturbado início de século, em que o combate pelas ideias liberais e constitucionais se fazia neste novo forum de discussão. Apesar da linguagem desbragada, contra os «periodiqueiros» e a "praga dos periódicos», interessa-nos, no momento, reter este texto como um exemplo paradigmático da gradual afirmação da imprensa na vida política do país e também do envolvimento dos homens de letras na sua dinâmica.

Este envolvimento arrasta-se ao longo de toda a época oitocentista e já no final do século, não esqueçamos, começam a fundar-se associações de profissionais que visavam a defesa dos homens de letras e dos jornalistas: a Associação de Jornalistas e Escritores Portugueses, em 1880, a Associação de Jornalistas e Homens de Letras do Porto, em 1882, a Associação dos Jornalistas, em 1896, a Associação da Imprensa Portuguesa, em 1897, etc. Como explica Isabel Vargues, a primeira foi criada em Lisboa, "no âmbito do programa das comemorações camonianas, com o fim de estabelecer uma biblioteca de jornalismo e de lançar o embrião de uma Escola de Jornalismo» ${ }^{18}$. A segunda, com sede no Porto, foi criada em homenagem póstuma ao grande jornalista António Rodrigues Sampaio, fundador d'A Revolução de Setembro, e «foi a associação de imprensa mais duradoura em Portugal, alcançando grande prestígio» ${ }^{19}$. Quer isto dizer que, mesmo no âmbito do movimento associativo profissional, detectamos esta aliança entre escritores, homens de letras, e jornalistas. Desde os escritores da primeira geração romântica, como Garrett e Herculano, passando por Feliciano de Castilho, Lopes de Mendonça, Camilo Castelo Branco, Pinheiro Chagas, quase todos os membros da Geração de 70, até aos poetas finisseculares como Fialho

\footnotetext{
16 «Tendo participado acesamente no polémico projecto da Constituição portuguesa e colaborado inicialmente com o vintismo, ele acabou por recusar o liberalismo em curso, fixando-se na superconservadora falange miguelista, e, em publicações soltas ou periódicas, despejou toda a sua bílis contra os herdeiros retardados da Revolução Francesa.» (In: Machado, Álvaro Manuel (dir. e org.) - Dicionário de Literatura Portuguesa. Lisboa, Caminho, 1996. 1. ${ }^{a}$ ed., p. 288.

${ }^{17}$ Referimo-nos a um recente estudo de Jorge Pedro Sousa, efectuado em Setembro de 2007: Sousa, Jorge Pedro - «Produção bibliográfica portuguesa sobre jornalismo até à Revolução de 25 de Abril de 1974». In: Intercom - Sociedade Brasileira de Estudos Interdisciplinares da Comunicação. XXX Congresso Brasileiro de Ciências da Comunicação, Santos. 29 de Agosto a 2 de Setembro de 2007.

${ }^{18}$ Vargues, Isabel - Ibidem. p. 168.

${ }^{19}$ Idem - Ibidem. p. 170.
} 
de Almeida, Afonso Lopes Vieira, e muitos outros, todos os grandes nomes da nossa Literatura do século XIX estão irremediavelmente ligados à imprensa do seu tempo. Estes nomes são exemplos de como, desde o início da centúria de oitocentos, para além dos jornalistas de profissão, sem nenhuma preparação especial para a exercerem, ser jornalista era também uma ocupação para o homem de letras, cuja imagem pública estava intimamente associada à Literatura. Aliás, para José Tengarrinha, esta participação dos nossos escritores no jornal foi determinante para o incremento da qualidade da escrita jornalística no século XIX, comparativamente com o que ocorrera nos séculos precedentes.

4. Esta sobreposição dos campos literário e jornalístico, ambos em processo de autonomização ao longo do século, foi, como já referimos, uma marca característica do jornalismo francês, em que escritores como Balzac, Victor Hugo, Eugène Sue, Zola e tantos outros abrilhantaram as páginas dos periódicos não apenas através da publicação de ficção - recorde-se a importância capital do romance-folhetim, a partir da década de trinta —, mas também pela publicação de crónicas jornalísticas, outro género muito apreciado no jornalismo oitocentista e geralmente reservado às grandes penas. Ora, na nossa opinião, como em muitas outras áreas sócio-culturais oitocentistas, também o jornalismo português ostentou um "afrancesamento» indiscutível, pois todo o século XIX é marcado pela presença constante do escritor-jornalista, nas páginas dos periódicos da altura. Não apenas os já citados escritores romântico-liberais, mas também os elementos da famosa Geração de 70, participaram activamente na elaboração e direcção de muitos periódicos ${ }^{20}$. Assim, uma História da imprensa periódica portuguesa passa obrigatoriamente pela história da afirmação e consolidação da elite intelectual e cultural oitocentista. Ou, como conclui Fátima Outeirinho, «atentar pois na faceta de cronista, jornalista ou tradutor de um autor é contribuir para uma tomada de consciência da multiplicidade de relaçôes que o campo literário estabelece dentro do campo cultural.» ${ }^{21}$.

O jornalismo era também encarado pelos homens de letras e pelos políticos como um patamar de acesso a outras carreiras ou funçôes, uma passagem obrigatória para abrir portas e conseguir uma promoção sócio-profissional. Numa análise às nossas elites intelectuais da primeira metade de oitocentos, Maria de Lourdes Lima dos Santos constata precisamente este aspecto: «O jornalismo, mais do que uma alternativa, aparecia como um modelo relativamente rápido e fácil para fazer uma reputação,

${ }^{20}$ A título de exemplo recorde-se que Ramalho Ortigão se revela, desde muito jovem, um activo colaborador em jornais e revistas do tempo, tendo escrito para O Jornal do Porto, para a Gazeta Literária, para a Gazeta de Notícias do Rio de Janeiro e para a Revista Contemporânea e continua a publicar, mesmo depois de Eça de Queirós abandonar o projecto em 1872, as suas Farpas. Oliveira Martins colabora com A Revolução de Setembro e com O Jornal do Comércio desde finais da década de sessenta, dirige, com Antero e Batalha Reis, a Revista Ocidental, em 1875, e funda dois jornais nos anos oitenta: A Província do Porto e $O$ Repórter de Lisboa. Também Teófilo Braga, outro membro da Geração de 70, prestou uma intensa colaboração em variados jornais: O Instituto, A Grinalda, O Ocidente e a Revista de Portugal. Batalha Reis escreve para $O$ Repórter e para a Gazeta de Notícias, entre 1888 e 1896, um conjunto de crónicas sob o título «Revista Inglesa» e colabora em variados periódicos: A Ilustração Diário de Notícias, A Luta.

${ }^{21}$ Outeirinho, Fátima - Ibidem, p. 91. 
valorizar-se e começar a escalada para a desejada meta. Fazer jornalismo (e particularmente jornalismo político) significava enveredar por uma via promocional que, nos novos tempos, exercia sobre os jovens desfavorecidos um poder de atracção comparável ao da carreira eclesiástica no antigo regime.» ${ }^{22}$.

O carácter provisório da actividade jornalística e o facto de esta actividade funcionar em paralelo com outras carreiras são sinais claros de que, ao longo de todo o século XIX, sobretudo até à década de 90, a profissão de jornalista teve de percorrer um lento caminho em direcção à sua autonomização, que só se atinge, como dissemos, quando começam a organizar-se as associações profissionais e os congressos do fim-de-século. Este fenómeno verificado na história do jornalismo português é comum a outros países europeus, nomeadamente a França onde, ao longo de toda a centúria de oitocentos, o jornal ou a revista são os espaços de promoção, publicidade e afirmação pública dos homens de letras. Como explica Thomas Ferenczi, referindo-se à participação dos homens de letras no campo jornalístico, o jornalismo é sobretudo uma via de passagem e não um local de chegada, ele é sobretudo importante por facilitar o acesso a certos patamares sócio-profissionais ${ }^{23}$; também para Christian Delporte a maioria dos contemporâneos viam o jornalismo como uma experiência, um ritual de passagem, uma etapa que poderia conduzir a uma celebridade rápida, funcionando como a antecâmara da literatura ou do $\operatorname{poder}^{24}$.

Um romance queirosiano como A Capital! ${ }^{25}$ dá-nos bem a ideia de como a figura do jornalista era projectada como uma importante influência em determinados meios, nomeadamente na estreia de jovens escritores e artistas. Artur Corvelo, protagonista do romance que anseia com uma vida de sucesso na capital, é conduzido pelos meios artísticos pela mão do pouco escrupuloso jornalista Melchior que, utilizando as páginas do «Século», jornal em que trabalhava, publicita o drama do jovem dramaturgo e o apresenta a deputados e artistas. Curiosamente, a ficção europeia, nomeadamente a francesa, revela uma propensão para retratar jornalistas nos seus enredos, geralmente conotando-os disforicamente com indivíduos sem escrúpulos, de duvidosa aptidão técnica e carreiristas sociais. Leiam-se Bel-Ami de Maupasant ou Illusions Perdues de Balzac para se ter uma ideia do olhar que os grandes romancistas da época lançaram sobre jornais, jornalistas e imprensa.

A falta de preparação para a profissão e a sua frágil autonomia são aspectos a ter em consideração quando se fala na projecção ficcional de jornalistas e de jornalismo. Estamos convictos de que a imprensa, ao longo de todo o século XIX, foi um albergue profissional para um vasto grupo de pessoas de proveniência social, cultura e formação muito díspares e que, se olharmos para os tipos queirosianos como Melchior Cordeiro d'A Capital! ou Palma Cavalão d'Os Maias percebemos que eles são precisamente o

\footnotetext{
22 Santos, Maria de Lourdes Lima dos - Intelectuais Portugueses na primeira metade de oitocentos. Lisboa, Editorial Presença, 1985, p. 332.

${ }^{23}$ Ferenczi, Thomas - Ibidem, p. 29.

${ }^{24}$ Delporte, Christian - Les journalistes en France 1880-1950. Naissance et construction d'une profession. Paris, Ed. du Seuil, 1999, p. 17.

${ }^{25}$ A Capital! é um romance póstumo publicado em 1925 pelo filho do romancista, provavelmente escrito no final dos anos setenta.
} 
produto acabado dessas discrepâncias. Atentemos nas palavras de outro censor da sociedade portuguesa finissecular — Fialho de Almeida — também ele um activo e frequente colaborador na imprensa do seu tempo, sobretudo como cronista ${ }^{26}$ :

«(...) o repórter português não corresponde nitidamente ao repórter do jornalismo lá de fora. Sai dos déclassés que as escolas rejeitaram, e dos tipos frustres que se quiseram eximir às profissões francamente laboriosas e correntes. Não é um homem de letras, e por outro lado falta-lhe educação que o transforme num crítico incisivo dos acontecimentos que desfilam; é literatiço falho, artigoleiro sem predicados de moralista, a posição especial que ele se fez no jornalismo, onde ninguém tem consciência das responsabilidades do seu papel, permite-lhe o gozo da imunidade de que ele abusa, e dá margem a exorbitâncias profissionais de que ele se vangloria.» ${ }^{27}$

O excerto citado é parte integrante de um dos folhetos panfletários dos seus célebres Os Gatos, publicados, como se sabe, entre 1889 e 1894 . Vale a pena, na nossa opinião, determo-nos na análise de alguns aspectos deste texto pois acreditamos que ele ilustra algumas das ilações a que fomos chegando ao longo deste trabalho. Ressalta destas palavras do autor a impreparação dos repórteres, provenientes de uma classe sem escolaridade, deficitária do ponto de vista da cultura e da formação, por clara oposição aos homens de letras. Assim, de facto, se confirma, pelas palavras de Fialho de Almeida, a convivência entre escritores, eruditos e homens da pena, com outros jornalistas, com pouca preparação, sem aptidão técnica específica, para quem os jornais, em expansão ao longo do século, surgiam como um último reduto. Certamente que esta dicotomia criava tensões no campo jornalístico, bem patentes nas palavras do escritor-jornalista, para mais tendo em consideração a evolução da imprensa no final do século, no sentido de privilegiar cada vez mais um conjunto de estratégias comerciais que ditavam a sedução da massa de leitores.

Ora, em nossa opinião, o modo como a literatura europeia plasmou a imagem dos jornais e dos jornalistas, conotando-a negativamente, deriva, em grande parte desta tensão: por um lado, o homem de letras, cultivado, erudito, criador de textos de autor, por outro lado, o repórter que, como comenta Fialho, tinha de «encher o número» do jornal, nem que para tal tivesse de recorrer a «um amontoado de inconsequências, de perfídias, de baixezas e de calúnias.»

Daqui decorrem consequências a vários níveis, sendo a mais evidente o facto de o escritor/homem de letras, afeito desde o início do século a ocupar um lugar dominante no universo da imprensa, quer como folhetinista, quer como cronista ou fazedor de opiniāo, se ver ultrapassado por um conjunto de mudanças que prescindiam da sua erudição e do seu saber, em benefício de um conjunto de "artigoleiros», sem ética nem moral, facilmente ajustáveis aos gostos do público, progressivamente direccionados

\footnotetext{
${ }^{26}$ Fialho de Almeida "começa a tornar-se famoso quer como contista quer sobretudo como cronista, pela sua colaboração em periódicos como Novidades (...), O Repórter, Pontos nos II, (...) Correio da Manhã, O Contemporâneo (...)» e muitos outros. (In: Machado, Álvaro Manuel - Ibidem. p. 23).

${ }^{27}$ Almeida, Fialho de - Os Gatos. Selecção e introdução por Maria Antónia Carmona Mourão e Maria Fernanda Pereira Nunes. Lisboa, Ulisseia, 1986, p. 139. (Negritos da nossa responsabilidade).
} 
para um jornalismo sensacionalista e hipersensível, do tipo da yellow press norteamericana.

Apesar de esta bipolarização no campo da imprensa ser um facto, aliás decorrente da falta de autonomia da profissão que, como dissemos, só se consegue a partir da organização de congressos, associaçōes e sindicatos, na transição do século XIX para o século XX, o homem de letras, escritor e intelectual, mantém-se integrado no movimento jornalístico, ora colaborando como cronista, ora assumindo-se como o folhetinista de serviço, ora escrevendo opinião e publicando ficção. Não esqueçamos que um dos momentos cruciais de intervenção no espaço público, neste fim-de-século, foi da lavra de um grande escritor: trata-se da célebre carta «J'accuse!», dirigida ao Presidente francês e publicada no jornal L'Aurore, a propósito da condenação do Capitão Dreyfus.

5. Uma outra motivação que atraía os homens de letras para o mundo da imprensa tinha que ver com os proveitos financeiros. Num país marginal como o nosso, com público restrito, poucos leitores e um fraco mercado livreiro, os dividendos adquiridos da escrita jornalística representavam uma mais-valia considerável que compensava os parcos proventos da venda dos livros ${ }^{28}$. O caso de Eça é exemplar no que a este aspecto diz respeito, pois a carreira de correspondente de imprensa permitia-lhe equilibrar melhor as suas complicadas finanças, embora, depois de uma análise pormenorizada dos contratos entre Eça de Queirós e os seus editores, Fernando Guedes conclua que Eça de Queirós, no final do século, era o escritor português mais bem pago da época ${ }^{29}$. Como explica Elza Miné, «se, na segunda, metade do século XIX, colaborar em jornais e revistas acabou por constituir-se, para tantos escritores, além de elo directo com seu público, suplemento orçamentário indiscutível, e se também nesse tempo a versatilidade era a qualidade que, por excelência, caracterizava o jornalista completo, não estranha que o jornal se constituísse num laboratório privilegiado da palavra e que a produção dessa espécie de jornalista que foi Eça de Queirós se inclua, de fato e de direito, no domínio do literário.» ${ }^{30}$.

Bastará, para o comprovarmos, lermos algumas das cartas que Eça dirigiu aos amigos mais próximos para nos apercebermos desta realidade. Em carta dirigida a

\footnotetext{
${ }^{28}$ Remetemos para a análise circunstanciada de Maria de Lourdes Lima dos Santos: Santos, Maria de Lurdes - Ibidem, p. 187-227.

29 «Também os seus proventos de escritor se tornaram significativos: de Os Maias, em 1883 e 1888 , recebeu um conto de réis; A Relíquia, em 1885, rendeu-lhe também um conto de réis; a Correspondência de Fradique Mendes, em 1889, traz-lhe quatrocentos mil réis; A Cidade e as Serras, em 1895, trezentos mil réis de adiantamento; A Ilustre Casa de Ramires, em 1899, outro adiantamento de trezentos mil réis. Em moeda de hoje são cerca de $4.800 .000 \$ 00$ a que se deve acrescentar o que foi recebendo pelas novas ediçôes do Crime e do Primo Basílio (...): $180 \$ 000$ (...) pela 3. a edição do Crime; $90 \$ 000$ (...) pela 3.a edição do Primo Basílio e o que há a acrescentar da colaboração na imprensa brasileira e na portuguesa (...)» (Guedes, Fernando - O Livro e a Leitura em Portugal. Subsídios para a sua História. Séculos XVIII-XIX. Lisboa e São Paulo, Editorial Verbo, 1987, p. 230-231).

${ }^{30}$ Miné, Elza - Páginas Flutuantes - Eça de Queirós e o Jornalismo do Século XIX. S. Paulo, Ateliê Editora, 2000, p. 49.
} 
Alberto de Oliveira, datada de 23 de Janeiro de 1896, Eça diz, a propósito da sua colaboração na Gazeta de Notícias do Rio:

"Ora o meu amigo sabe que eu sou, tenho sido nestes últimos anos, um redactor regular da Gazeta de Notícias do Rio, recebendo um salário regular. Em mais de quatro meses, não mandei à Gazeta o valor, em prosa, de um bilhete-postal. Também por escrúpulo, não tendo dado o trabalho, não cobrei o salário. Mas esses salários são indispensáveis ao meu orçamento - e para legitimamente os receber agora, tenho de mandar para o Rio o montão de prosa a que eles correspondem e que os justifica.»

(Queirós, Eça de - Correspondência. Coordenação, prefácio e notas de Guilherme de Castilho. Lisboa, I.N.C.M., 1983. $1^{\circ}$ e $2^{\circ}$ Vols., p. 360).

Esta carta é um dos muitos exemplos de como era importante para o autor enviar com regularidade textos para os jornais: Eça necessitava, para viver de acordo com o nível de vida a que se habituara, de ganhar o dinheiro destas colaborações ${ }^{31}$. Não se pense, no entanto, que eram apenas as motivações financeiras que impeliam o escritor para as páginas dos jornais. A qualidade estética dos seus textos deixa perceber, de facto, que Eça também escrevia por prazer e por desafio intelectual, como, aliás, deixa bem expresso em carta dirigida a Ramalho Ortigão, a 10 de Julho de 1879, um ano antes, portanto, de iniciar a sua colaboração com a Gazeta de Notícias do Rio de Janeiro:

«Meu pai escreveu-me há dias, falando-me do desejo que tinha Gonçalves Crespo (...) em me convidar para mandar correspondências ao "Jornal do Comércio». Isto vem exactamente combinar com o meu próprio desejo; eu necessito fazer correspondências, por higiene intelectual. Tenho-me posto no mau hábito de ler todas as manhãs montões de jornais: e esta grossa massa de política cai-me no cérebro, não é digerida, e pela sua presença impede o jogo regular das faculdades artísticas. (...) Preciso purgar a inteligência destas fezes. Quero um vaso.

$\mathrm{O}$ «Jornal do Comércio» parece-me preencher esta função útil» (Queirós, Eça de - Ibidem, p. 180).

A escrita jornalística constituía, então, para Eça uma forma de catarse e de organização mental: a massa de informação recebida e absorvida pela leitura de jornais era a matéria-prima que as correspondências do autor trabalhavam, moldavam e reinterpretavam. Apesar de tudo, como o excerto da carta deixa perceber, os jornais não eram tidos em grande consideração pelo cronista que os olhava quer como um meio de ganhar dinheiro, quer como uma forma de «vazar» algumas ideias acumuladas que lhe poderiam perturbar a criação literária, afinal, a grande paixão de Eça.

${ }^{31}$ Como explica Carlos Reis, referindo-se à correspondência parisiense, «n'oublions pas que ces collaborations journalistiques répondaient aussi à la nécessité de gains supplémentaires, ressentie par un Eça que harcelaient les difficultés financières, aggravées par les exigences d'une famille déjà relativement nombreuse, dans une ville chère comme Paris.» (Reis, Carlos - Eça de Queirós Consul de Portugal à Paris 1888-1900. Paris, Centre Culturel C. Gulbenkian, 1997, p. 110). 
Face a este aparente desprezo pelos jornais e da já conhecida motivação financeira que conduzia o escritor para a escrita mais utilitária, as páginas jornalísticas de Eça de Queirós revelam, em nossa opinião, uma qualidade surpreendente, em nada inferior à das obras literárias. Espraiados entre a década de 60, até ao momento da sua morte, estes textos, na sua maioria de dimensão epistolar, dedicam-se a temas muito diversificados, revelam diferentes níveis de profundidade e estilos bem diversos. Essencialmente inspirados na leitura dos periódicos ingleses e franceses, que Eça lia em quantidade e variedade, eles transmitem-nos uma visão caleidoscópica da Europa do tempo, sempre filtrada pelo olhar atento e crítico do escritor-jornalista.

Desde as remotas crónicas de política internacional do jornal Distrito de Évora, até às dezenas de cartas com que exerceu as funçôes de correspondente europeu da Gazeta de Notícias, o leitor consegue compor o puzzle dos acontecimentos políticos, sociais e culturais mais marcantes da segunda metade do século, desde a Guerra russo-turco, aos desígnios imperialistas ingleses, passando pelas greves operárias do mundo anglo-saxónico ou por acontecimentos como a Grande Exposição Universal de Paris. Naturalmente que todos estes acontecimentos, filtrados da imprensa internacional, são expostos em discursos de clara dimensão opinativa, em que impera a subjectividade e o ponto de vista do cronista. Através destes textos de imprensa, conseguimos perceber a mundividência do escritor, a sua inimitável ironia e a sua eterna propensão para a crítica social, sobretudo quando o alvo é Portugal, país de onde se encontra ausente, mas nem por isso menos presente na mente do escritor jornalista. Leiam-se os textos de Cartas de Londres, publicados n'A Actualidade do Porto, ou algumas crónicas de Cartas de Inglaterra, publicadas serialmente na Gazeta de Notícias, para se perceber que, mesmo comentando situações socio-políticas europeias, é Portugal o destinatário visado.

A leitura da sua vastíssima colaboração cronística e epistolar também nos permitirá verificar a persistência de um conjunto de estratégias discursivas e narrativas mais próximas do ideal jornalístico pré-industrial do que propriamente a submissão aos novos padrões de escrita: o persistente recurso à forma epistolar, a propensão narrativa dos textos, a persistência do discurso descritivo, a literariedade de algumas crónicas, o diletantismo temático e a forte presença da opinião e da subjectividade discursiva são estratégias típicas de um jornalismo literário que insiste em resistir à vaga anglo-americana, que começava a invadir a imprensa europeia no final do século. Estamos certas de que a prática jornalística queirosiana traduz o ideal de um jornalismo interventivo, empenhado e, sobretudo, construído com os cuidados e a elevação que uma escrita literária merece.

6. Para concluirmos, resta-nos sublinhar que é precisamente esta valorização literária dos textos de imprensa queirosianos que permitiu que eles fossem resistindo ao tempo e vencendo a efemeridade que geralmente afecta textos jornalísticos. Embora circunscritos a contextos precisos e retratando cenários históricos circunscritos, estas crónicas possuem uma dimensão atemporal que ainda hoje suscita releituras e interpretações. Ora, num colóquio como este, intitulado «Outros Combates pela História», parece-nos que o exemplo de um homem de letras como Eça de Queirós nos pode levar a questionar até que ponto a imprensa não começa a ser, a partir do século XIX, um instrumento fundamental da escrita da História, tendo sobretudo em consideração, 
por um lado, os agentes fulcrais deste jornalismo — os escritores e homens de letras - e, por outro, uma visão lata da historiografia enquanto a narrativa de um certo período de tempo. Uma narrativa, acrescentamos, construída como um palimpsesto, em que todos os produtos culturais de uma época são chamados à colação. Permitam-me que termine citando um outro escritor-jornalista, mais recente e também inquietado com estas questóes da História: «basta-me pensar [diz José Saramago] que sempre será melhor ciência aquela que for capaz de me proporcionar uma compreensão duplicada: a do Homem pelo Facto, a do Facto pelo Homem.» 32

Ora, o caso que aqui apresentámos, o de Eça de Queirós, é apenas um dos mais conhecidos, afamados e estudados, dentre um riquíssimo manancial de homens e mulheres de letras que, ao longo de todo o século XIX, se dedicaram à escrita jornalista, integrando de facto e de direito a História da Imprensa portuguesa. Neste sentido, a nossa abordagem deixa algumas pistas de investigação, constatando-se que muito ainda há para trabalhar neste domínio.

\section{BIBLIOGRAFIA ACTIVA}

Almeida, Fialho de - Os Gatos. Selecção e Introdução por M. Antónia Mourão e M. Fernanda Nunes. Lisboa, Ulisseia, 1986.

Macedo, José Agostinho de - Exorcismos contra Periódicos e outros malefícios. Lisboa, Oficina da Viúva de Lino da Silva Godinho, 1821.

Queirós, Eça de - A Capital! (começos duma carreira). Edição Crítica de Luiz Fagundes Duarte. Lisboa, INCM, 1992.

Queirós, Eça de - Correspondência. Organização e Edição de Guilherme de Castilho. Lisboa, INCM, 1983. Vol. I.

Saramago, José - «História e ficção». In: Jornal de Letras, Artes \& Ideias. 6 de Março de 1990, p. 17-19.

\section{Bibliografia CRÍTICA}

Baptista, Jacinto - «Eça jornalista». In: Matos, A. Campos - Dicionário de Eça de Queiroz. Lisboa, Caminho, 1993, 2. ${ }^{\text {e ed., p. } 326 .}$

Brasil, Jaime - «Eça de Queiroz, jornalista». In: Pereira, Lúcia Miguel e Reis, Câmara (Org.) - Livro do Centenário de Eça de Queiroz. Lisboa, Livros do Brasil, 1945.

Chalaby, Jean - «O Jornalismo como invenção anglo-americana. Comparação entre o desenvolvimento do jornalismo francês e anglo-americano (1830-1920)». In: Media \& Jornalismo, Nov. 2003, Vol. 1, n. ${ }^{\circ} 3$, p. 6. (http://revcom.portcom.intercom.org.br).

Coelho, Jacinto do Prado - Dicionário de Literatura. Porto, Figueirinhas, 1994. Vol. II, p. 588-589.

Delporte, Christian - Les journalistes en France 1880-1950. Naissance et construction d'une profession. Paris, Ed. du Seuil, 1999.

Ferenczi, Thomas - L'invention du journalisme en France. Naissance de la presse moderne à la fin du XIXe siècle. Paris, Plon, 1993.

\footnotetext{
32 Saramago, José - «História e ficção». In: Jornal de Letras, Artes \& Ideias. 6 de Março de 1990, pp. 17-19.
} 
Guedes, Fernando - O Livro e a Leitura em Portugal. Subsidios para a sua História. Séculos XVIII-XIX. Lisboa e São Paulo, Editorial Verbo, 1987.

Machado, Álvaro Manuel (dir. e org.) - Dicionário de Literatura Portuguesa. Lisboa, Caminho, 1996. 1. a ed.

Matos, A. Campos - Dicionário de Eça de Queiroz. Lisboa, Caminho, 1993, 2. ${ }^{\mathrm{e}} \mathrm{d}$.

Miné, Elza - Páginas Flutuantes - Eça de Queirós e o Jornalismo do Século XIX. S. Paulo, Ateliê Editora, 2000.

Outeirinho, Fátima - "A imprensa periódica e o folhetim na vida do homem de letras oitocentista». In: Queirosiana. Estudos sobre Eça de Queirós e sua Geração. Tormes, Fundação Eça de Queiroz. n.o 11/12, p. 81-92.

Reis, Carlos - Eça de Queirós Consul de Portugal à Paris 1888-1900. Paris, Centre Culturel C. Gulbenkian, 1997.

Santos, Maria de Lourdes Lima dos - Intelectuais Portugueses na primeira metade de oitocentos. Lisboa, Editorial Presença, 1985.

Sousa, Jorge Pedro - «Produção bibliográfica portuguesa sobre jornalismo até à Revolução de 25 de Abril de 1974». In: Intercom - Sociedade Brasileira de Estudos Interdisciplinares da Comunicação. XXX Congresso Brasileiro de Ciências da Comunicação, Santos. 29 de Agosto a 2 de Setembro de 2007.

Tengarrinha, José - História da Imprensa Periódica Portuguesa. Lisboa, Caminho, 1989. 2.a ed., p. 191.

Thérenty, Marie-Ève - Mosäques. Être écrivain entre presse et roman (1829-1836). Paris, Honoré Champion, 2003.

Vargues, Isabel Nobre - "A Afirmação da Profissão de Jornalista em Portugal: um poder entre poderes?». In: Separata da Revista de História das Ideias. Coimbra, Faculdade de Letras, 2003. Vol. 24.

Venâncio, Fernando - «A Linguagem da Imprensa Portuguesa (1840-1870). Os testemunhos contemporâneos». In: Arquivos do Centro Cultural Calouste Gulbenkian. Lisboa-Paris, Centro Cultural Calouste Gulbenkian, 1996. Vol. XXXV, p. 381-391. 

Série

Documentos

Imprensa da Universidade de Coimbra

Coimbra University Press

2010

- U

C • 